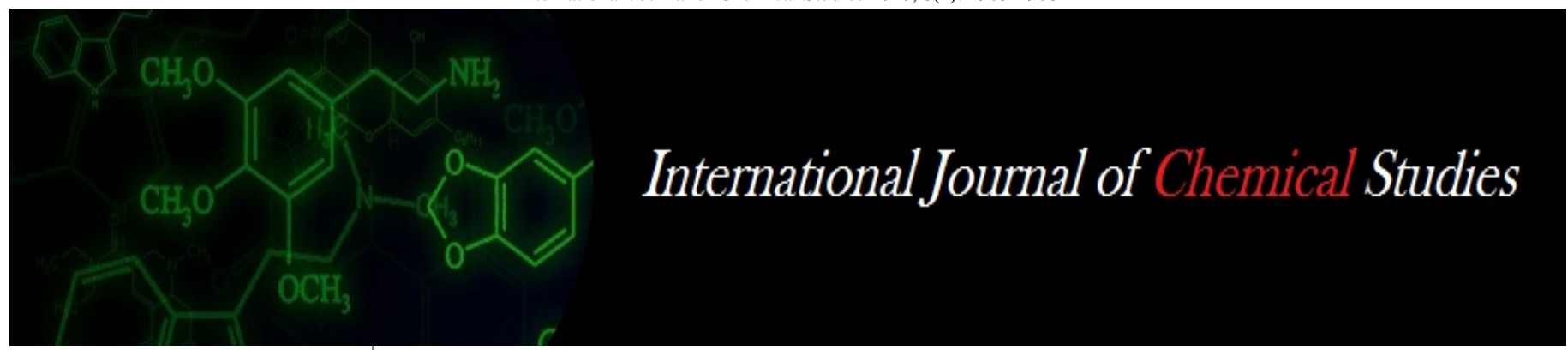

P-ISSN: 2349-8528

E-ISSN: 2321-4902

www.chemijournal.com

IJCS 2020; 8(4): 2905-2908

(C) 2020 IJCS

Received: 17-05-2020

Accepted: 20-06-2020

RP Singh

HOD Biochemistry, Department

of Biochemistry, ANDUAT,

Kumarganj, Ayodhya, Uttar

pradesh, India

Aman Pratap Singh

Research Scholar, Department of

Biochemistry, ANDUAT,

Kumarganj, Ayodhya, Uttar

pradesh, India

Ramesh Pratap Singh

Assistant Professor, Department

of Biochemistry, ANDUAT,

Kumarganj, Ayodhya, Uttar pradesh, India

RN Kewat

Associate Professor, Department. of Agricultural Biochemistry,

ANDUAT, Kumarganj,

Ayodhya, Uttar pradesh, India

Corresponding Author:

RP Singh

HOD Biochemistry, Department

of Biochemistry, ANDUAT,

Kumarganj, Ayodhya, Uttar

pradesh, India

\section{Biochemical studies on Mango (Mangifera Indica L.) varieties during various stages of fruit development}

\author{
RP Singh, Aman Pratap Singh, Ramesh Pratap Singh and RN Kewat
}

DOI: $\underline{\text { https://doi.org/ 10.22271/chemi.2020.v8.i4ai.10084 }}$

\begin{abstract}
The present investigation was conducted on ten varieties of mango collected from orchard at ANDUAT, Kumarganj, Ayodhya to study physical and biochemical parameters during various stages of fruit development. Highest total sugar content was observed in Amrapali (6.52\%) at 30 days and $13.05 \%$ at 60 days after fruit setting. Maximum ascorbic acid content was recorded in Gilash (26.73 mg/100g) at 30 days, Langra $(23.32 \mathrm{mg} / 100 \mathrm{~g})$ at 60 days and Gulabkhas $(19.83 \mathrm{mg} / 100 \mathrm{~g})$ at 90 days after fruit setting. Maximum beta carotene content was noticed in Amrapali $(124.94 \mu \mathrm{g} / 100 \mathrm{~g})$ at 30 days and 90 days $(3543.80 \mu \mathrm{g} / 100 \mathrm{~g})$. Maximum crude fibre content was noticed in Gilash $(1.28 \%)$ at 30 days and $(1.11 \%)$ at 60 days. Dashehari variety was found to contain highest amount of total sugar while highest ascorbic acid content was recorded in Gilash at 30 days and Gulabkhas at 90 days.
\end{abstract}

Keywords: Mango varieties, total sugar, protein, crude fibre, amino acid, total mineral

\section{Introduction}

The biochemical composition of mango fruit differs among the cultivars and the stage of maturity. Mango fruit is rich in carbohydrate as well as vitamin A and C. Mango peel and pulp contains other compounds, such as pigments, crotenoids, polyphenols, omega- 3 and omega- 6 polyunsaturated fatty acids. Mango peel contains pigments, including carotenoids, such as provitamin A compound, beta-carotene, lutein and alphacarotene, polyphenols such as quereetin, gallic acid, caffeic acid, catechins, tannins and the unique mango xanthonoid and mangiferin which have potential to counteract various disease processes. Phytochemical and nutrient content appears to vary across mango cultivars. Up to 25 different carotenoids have been isolated from mango pulp, the highest of which was beta-carotene, which accounts for the yellow orange pigmentation of most mango cultivars. Mango belongs to the genus Mangifera of the family anacardiaceae. The genus Mangifera contains several species that bear edible Mangifera species generally have lower quality fruits and are commonly referred to as wild mangoes. Fruits are highly perishable due to enzymatic and non-enzymatic reactions that takes place during maturation and storage, affecting nutritional, sensorial and physicochemical properties. Nutritionally it is a rich source of carotenoids organic acids, polyphenols and minerals etc. The quality of mango fruit is judged on the basis of shape, size, weight, maturity, firmness and golden yellow colour after ripening. There are nearly 1000 mango varieties in India, but only 20 are cultivated on a commercial scale. The famous and popular varieties are Alphanso, Bombay Green (Malda), Chausa, Dasheehri, Lagara, Safeda, Neelam, Malgova and Banglora (Totapari).

All the parts of mango plant have various uses in India. Both ripe and unripe fruits are used extensively by food processing industries to prepare wide variety of products such as syrup, jam squash, juice, amchur, candy, jam jelly preserve and squash etc. Ripe fruits are utilized in preparing nectar, custard powder, baby foods, mango leather and toffee also. The kernel obtained after decortication of mango stone can be utilized as a supplement to wheat flour or for extraction of edible oil. Besides its use in animal feed, mango keernel flour can be utilized for edible purposes. Besides fruits of some cultivars like Alphanso and Dashehari are sliced and canned for catering to the needs of consumers during the off-season. 
Alphonso was found to be the most suitable for canned juice preparation due to its attractive colour, consistency and flavor. Mango plant is used in the worship by Hindu religion. Very rare literature is available on biochemical changes in various stages of growth and development in improve mango varieties. Therefore, present research work has been conducted on biochemical changes in mango varieties during their fruit development stage.

\section{Materials and Methods}

Ten varieties of mango fruit namely Dashehari, Safeda, Amrapali, Gulab khash, Ramkela, Sukul, Rataul, Langara, Gilash and Totapari were used as experimental material which were collected at 30, 60 and 90 days after fruit setting from the orchard at ANDUAT Kumarganj, Ayodhya. The skin colour of above varieties were recorded by visual observation while length and breadth were noticed at 30, 60 and 90 days after fruit setting. Similarly rate of mango fruit and mango kernel were also observed at different interval. The biochemical parameters namely reducing sugar, total sugar (Dubois et al. 1956) ${ }^{[4]}$ and ascorbic acid (AOAC 1970) ${ }^{[1]}$ were analyse at various intervals. The content of beta carotene crude fibre and total mineral. Chlorophyll content Jayaraman 1981 and protein content were also determined at various intervals in the present research work.

\section{Results and Discussion}

The data regarding fruit colour at various stages were found as light green, dark green, light yellow, yellow, yellowest green and reddish green colour. Green colour at 30 days were recorded in Dasehari, Amarpali Safeda Gulabkhash, Totapari and Ramkela. Yellowish green colour was obtained in Gilash, sukul, Ramkela, Rataul. While reddish green colour in gulabkhash and Totapari and yellowish green colour in Dashehari, Rataul, Sukul and Gilash at 90 days. Singh et al. (2017) ${ }^{[14]}$ observed that fruit ripening is a complex process and fruit culinates in drastic changes in colour, texture, flavor and aroma in mango fruit. During ripening, formation of pigment especially carotenoids occurs. Payasi and Sunwal have reported that ripening is the final stage of fruit development, which involves series of physiological and biochemical events leading to change in colour, flavour and aroma content. The size of fruits i.e. Fruit length and breadth of different mango varieties in the present finding reveales that there was great variability appears in size of mango fruits. The average fruit length and breadth varied from 3.47$15.51 \mathrm{~cm}$ (length) and 2.07-10.01cm (breadth). (Table -2). All the varieties of mango were found statically significant regarding size of fruit. Siddig et al. (2016) observed that fruit size (length and width) in a major quality indices play main role for the success of any fruit cultivars. The weight of fruit ranged from 35.54-42.73g at 30 days, 110.01-148.53g at 60 days and 167.42-209.18g at 90 days after fruit setting. (Table$3)$. The variation in the fruit weight may be due to nutrients present in soil. Nitrogen in an extremely important element which forms part of structures of amino acids, nucleic acids while phosphorus exist as inorganic phosphorus or organic phosphate such as glucose 6-phosphate, ATP, phospholipids, DNA, RNA and phytic acid as given by Chesworth et al (1998) ${ }^{[3]}$. The weight of stone was obtained from 2.2-2.9 $\mathrm{g}$ at 30 days, 8.7-11.2g at 60 days and 18.4-25.0g at 90 days after fruit setting (Table-3). A continuous increasing in weight of mango stone was noticed from 30 to 90 days in various mango varieties. Singh et al. (2017) ${ }^{[14]}$ noticed that variation in the stone might to be result of alterations in absorption and translocation pattern of photosynthates, genetic composition and environmental factors.

Reducing sugar content varied from 2.36-4.05 percent at 30 days, 6.11-8.15 per cent at 60 days, $10.50-12.76$ per cent at 90 days after fruit setting (Table-4). The mango varieties showed an increasing concentration of sugar from 30 to 90 days. The conversion of starch to sugar is most remarkable chemical change occurring in mango pulp during fruit ripening. The total sugar content was noticed in the range of 4.48-6.52 percent at 30 days, 9.33-12.05 per cent at 60 days and 16.8920.01 percent at 90 days after fruit setting. (Table-5). Total sugar content was found in increasing pattern during ripening and the results are inconformity with the findings of Ooth 2013. The increase in total sugar content might be due to conversion of complex starch carbohydrates to simple compounds. Non reducing sugar were increased at ripe stage but slightly reduced at last edible stage as given by Azad et al. (2009) ${ }^{[2]}$.

Non-reducing sugar content varied from 2.16-2.48 per cent at 30 days, 2.22-2.91 percent at 60 days, 6.15-7.7.37 percent at 90 days, after fruit setting (Table-6). All the varieties were found significant regarding non-reducing sugar content. Ascorbic acid ranged from $23.26-26.73 \mathrm{mg} / 100 \mathrm{~g}$ at 30 days, $21.40-23.32 \mathrm{mg} / 100 \mathrm{~g}$ at 60 days, $16.82-19.83 \mathrm{mg} / 100 \mathrm{~g}$ at 90 days Table-7). A decreasing pattern of ascorbic acid content mango varieties was noticed from 30 days to 90 days after fruit setting. Highest concentration of ascorbic acid was recorded just after fruit setting and decreases during harvest and maturity stages. The content of ascorbic acid increases initially in the fruit while decreases during ripening stage. The reduction in vitamin $\mathrm{C}$ content of the fruit may be due to the susceptibility of ascorbic acid to oxidative destruction particularly at high ambient storage temperature as given by Hossain et al. (2014) ${ }^{[6]}$. Beta carotene content ranged from $95.11-124.94 \mu \mathrm{g} / 100 \mathrm{~g}$ at 30 days, $851.95-1442.71 \mu \mathrm{g} / 100 \mathrm{~g}$ at 60 days and 2572.63-3543.80 $\mu \mathrm{g} / 100 \mathrm{~g}$ at 90 days after fruit setting (Table-8). A regular increasing in the content of beta carotene was recorded from 30 to 90 days while maximum increasing in beta carotene was recorded from 60 to 90 days in fruits. The yellow orange colour of fruit might be due to carotenoids and increased concentration of beta carotene which may be due to degradation of chlorophyll and increased synthesis and accumulation of carotenoid in the plastids. Beta carotene is formed from a simple five carbon isoprenoid unit which involves a series of de-saturation reaction followed by cyclization of terminal bond finally converted into 40 carbon carotene as reported by Azad et al. (2009) ${ }^{[2]}$ while analysing mango fruits at different maturity stages.

The crude fibre content at 30 days, 60 days and 90 days were observed between $1.12-1.28$ percent, $0.88-1.11$ percent and $0.62-0.85$ percent respectively. A continuous decreasing in the crude fibre content was observed content was observed from 30 to 90 days in different mango germplasm. Crude fibre content has been found in decreasing pattern with ripening and maturity. Azad et al. (2009) ${ }^{[2]}$ studied ditry fiber and proximate composition of mango fruit during various stages and found decreasing pattern of crude fibre during maturity and harvest. Othaman and Mbogo (2009) [11] determine physicochemical characteristics of ripe mango and observed similar range of crude fiber. Total mineral content is influence by various factors like soil composition, climatic condition of the area of mango growth, the variety and level of farm management practices (tree and soil management especially fertilizer added during planting). The variability in mineral 
content was influenced by above factors as reported by Okoth et al (2003) (Table-9).

Table 1: Colour of mango fruits at different stages after fruit setting.

\begin{tabular}{|c|c|c|c|c|}
\hline \multirow{2}{*}{ S.No. } & \multirow{2}{*}{ Varieties } & \multicolumn{3}{|c|}{ Colour of fruits } \\
\cline { 3 - 5 } & & $\mathbf{3 0}$ days & $\mathbf{6 0}$ dady & 90 days \\
\hline 1 & Amrapali & Green & Dark green & Light Yellow \\
\hline 2 & Langara & Dark green & Light Green & Light Yellow \\
\hline 3 & Dashehari & Green & Dark green & Yellowish green \\
\hline 4 & Safeda & Green & Light Green & Yellow \\
\hline 5 & Rataul & Dark green & Dark green & Yellowish green \\
\hline 6 & Gulabkhash & Green & Light Green & Reddish green \\
\hline 7 & Totapari & Green & Light Green & Reddish green \\
\hline 8 & Ramkela & Green & Green & Yellowish green \\
\hline 9 & Sukul & Dark green & Dark green & Yellowish green \\
\hline 10 & Gilash & Dark green & Green & Yellowish green \\
\hline
\end{tabular}

Table 2: Size of mango fruits at different stages after fruit setting.

\begin{tabular}{|c|c|c|c|c|c|c|}
\hline \multirow{3}{*}{ Varieties } & \multicolumn{7}{|c|}{ Size of fruits (cm) } \\
\cline { 2 - 7 } & $\mathbf{3 0}$ days & \multicolumn{6}{|c|}{$\mathbf{6 0}$ day } & \multicolumn{2}{|c|}{ 90 days } \\
\cline { 2 - 7 } & $\mathbf{L}$ & $\mathbf{B}$ & $\mathbf{L}$ & $\mathbf{B}$ & $\mathbf{L}$ & $\mathbf{B}$ \\
\hline Amrapali & 4.35 & 2.59 & 7.82 & 4.58 & 10.76 & 7.12 \\
\hline Langara & 4.41 & 2.67 & 7.96 & 4.67 & 11.18 & 7.35 \\
\hline Dashehari & 4.47 & 2.76 & 7.94 & 5.22 & 11.29 & 7.44 \\
\hline Safeda & 3.70 & 2.07 & 7.25 & 4.14 & 10.73 & 6.74 \\
\hline Rataul & 3.97 & 2.34 & 7.26 & 3.69 & 9.72 & 6.42 \\
\hline Gulabkhash & 3.95 & 2.34 & 6.73 & 3.67 & 10.12 & 6.62 \\
\hline Totapari & 3.73 & 2.29 & 6.91 & 3.93 & 10.49 & 6.52 \\
\hline Ramkela & 3.47 & 2.12 & 6.90 & 3.68 & 9.61 & 6.47 \\
\hline Sukul & 3.50 & 2.32 & 6.95 & 3.56 & 9.44 & 6.45 \\
\hline Gilash & 3.67 & 2.32 & 6.72 & 3.51 & 9.28 & 6.32 \\
\hline SEm+ & 0.17 & 0.13 & 0.29 & 0.80 & 0.39 & 0.17 \\
\hline CD at $5 \%$ & 0.49 & 0.39 & 0.88 & 0.27 & 1.16 & 0.52 \\
\hline
\end{tabular}

Table 3: Weight of mango fruits at different stages after fruit setting.

\begin{tabular}{|c|c|c|c|c|}
\hline \multirow{2}{*}{ S.No. } & \multirow{2}{*}{ Varieties } & \multicolumn{3}{|c|}{ Weight of fruits } \\
\cline { 3 - 5 } & & $\mathbf{3 0}$ days & $\mathbf{6 0}$ day & $\mathbf{9 0}$ days \\
\hline 1 & Amrapali & 41.45 & 139.46 & 205.50 \\
\hline 2 & Langara & 41.83 & 142.92 & 209.18 \\
\hline 3 & Dashehari & 42.73 & 148.53 & 199.57 \\
\hline 4 & Safeda & 37.96 & 136.80 & 187.72 \\
\hline 5 & Rataul & 35.54 & 123.07 & 172.53 \\
\hline 6 & Gulabkhash & 36.66 & 124.05 & 175.51 \\
\hline 7 & Totapari & 39.80 & 121.18 & 178.72 \\
\hline 8 & Ramkela & 36.64 & 125.52 & 172.07 \\
\hline 9 & Sukul & 35.81 & 117.06 & 171.86 \\
\hline 10 & Gilash & 36.20 & 110.01 & 167.42 \\
\hline & SEm+ + & 1.18 & 5.56 & 5.60 \\
\hline & CD at $5 \%$ & 3.20 & 15.56 & 16.64 \\
\hline
\end{tabular}

Table 4: Reducing sugar content (\%) of mango fruits at different stages after fruit setting.

\begin{tabular}{|c|c|c|c|c|}
\hline \multirow{2}{*}{ S.No. } & \multirow{2}{*}{ Varieties } & \multicolumn{3}{|c|}{ Reducing sugar content (\%) } \\
\cline { 3 - 5 } & & $\mathbf{3 0}$ days & $\mathbf{6 0}$ day & $\mathbf{9 0}$ days \\
\hline $\mathbf{1}$ & Amrapali & $\mathbf{4 . 0 5}$ & $\mathbf{8 . 1 5}$ & $\mathbf{1 2 . 7 2}$ \\
\hline 2 & Langara & 3.91 & 7.93 & 12.76 \\
\hline 3 & Dashehari & 4.01 & 7.93 & 12.70 \\
\hline 4 & Safeda & 3.20 & 7.57 & 11.91 \\
\hline 5 & Rataul & 3.12 & 7.47 & 11.80 \\
\hline 6 & Gulabkhash & 2.99 & 6.92 & 11.90 \\
\hline 7 & Totapari & 2.90 & 6.59 & 11.32 \\
\hline 8 & Ramkela & 3.05 & 6.44 & 11.19 \\
\hline 9 & Sukul & 2.69 & 6.33 & 10.93 \\
\hline 10 & Gilash & 2.36 & 6.11 & 10.50 \\
\hline & SEm \pm & 0.11 & 0.17 & 0.17 \\
\hline & CD at $5 \%$ & 0.32 & 0.52 & 0.51 \\
\hline
\end{tabular}

Table 5: Non-Reducing sugar content (\%) of mango fruits at different stages after fruit setting.

\begin{tabular}{|c|c|c|c|c|}
\hline \multirow{2}{*}{ S.No. } & \multirow{2}{*}{ Varieties } & \multicolumn{3}{|c|}{ Non-reducing sugar content (\%) } \\
\cline { 3 - 5 } & & $\mathbf{3 0}$ days & $\mathbf{6 0}$ day & $\mathbf{9 0}$ days \\
\hline 1 & Amrapali & 2.48 & 4.91 & 7.37 \\
\hline 2 & Langara & 2.44 & 4.75 & 7.23 \\
\hline 3 & Dashehari & 2.35 & 4.56 & 7.31 \\
\hline 4 & Safeda & 2.32 & 3.66 & 6.61 \\
\hline 5 & Rataul & 2.31 & 3.57 & 6.53 \\
\hline 6 & Gulabkhash & 2.25 & 3.53 & 6.55 \\
\hline 7 & Totapari & 2.23 & 4.10 & 6.67 \\
\hline 8 & Ramkela & 2.30 & 3.35 & 6.28 \\
\hline 9 & Sukul & 2.16 & 3.33 & 6.18 \\
\hline 10 & Gilash & 2.16 & 3.22 & 6.15 \\
\hline & SEm + & 0.03 & 0.16 & 0.23 \\
\hline & CD at $5 \%$ & 0.10 & 0.48 & 0.67 \\
\hline
\end{tabular}

Table 6: Total sugar content (\%) of mango fruits at different stages after fruit setting.

\begin{tabular}{|c|c|c|c|c|}
\hline \multirow{2}{*}{ S.No. } & \multirow{2}{*}{ Varieties } & \multicolumn{3}{|c|}{ Total sugar content (\%) } \\
\cline { 3 - 5 } & & $\mathbf{3 0}$ days & $\mathbf{6 0}$ day & $\mathbf{9 0}$ days \\
\hline 1 & Amrapali & 6.32 & 13.05 & 19.95 \\
\hline 2 & Langara & 6.35 & 12.69 & 19.99 \\
\hline 3 & Dashehari & 6.36 & 12.49 & 20.01 \\
\hline 4 & Safeda & 5.52 & 11.27 & 18.46 \\
\hline 5 & Rataul & 5.43 & 11.04 & 18.33 \\
\hline 6 & Gulabkhash & 5.24 & 10.44 & 18.58 \\
\hline 7 & Totapari & 5.14 & 1069 & 17.66 \\
\hline 8 & Ramkela & 5.70 & 9.79 & 17.47 \\
\hline 9 & Sukul & 4.48 & 9.66 & 17.11 \\
\hline 10 & Gilash & 4.56 & 9.33 & 16.89 \\
\hline & SEm \pm & 0.12 & 0.28 & 0.24 \\
\hline & CD at $5 \%$ & 0.35 & 0.84 & 0.73 \\
\hline
\end{tabular}

Table 7: Ascorbic acid content (mg/100g) of mango fruits at different stages after fruit setting.

\begin{tabular}{|c|c|c|c|c|}
\hline \multirow{2}{*}{ S.No. } & \multirow{2}{*}{ Varieties } & \multicolumn{4}{|c|}{ Ascorbic acid content (mg/100g) } \\
\cline { 3 - 5 } & & $\mathbf{3 0}$ days & $\mathbf{6 0}$ day & $\mathbf{9 0}$ days \\
\hline 1 & Amrapali & 26.38 & 22.99 & 18.66 \\
\hline 2 & Langara & 25.78 & 23.32 & 19.07 \\
\hline 3 & Dashehari & 26.11 & 22.70 & 17.43 \\
\hline 4 & Safeda & 23.99 & 21.86 & 16.82 \\
\hline 5 & Rataul & 24.31 & 22.89 & 17.99 \\
\hline 6 & Gulabkhash & 25.98 & 23.03 & 19.83 \\
\hline 7 & Totapari & 23.26 & 21.40 & 17.83 \\
\hline 8 & Ramkela & 25.18 & 22.05 & 18.74 \\
\hline 9 & Sukul & 26.14 & 22.58 & 18.53 \\
\hline 10 & Gilash & 26.73 & 22.60 & 19.40 \\
\hline & SEm + & 0.29 & 0.38 & 0.38 \\
\hline & CD at $5 \%$ & 0.87 & 1.13 & 0.84 \\
\hline
\end{tabular}

Table 8: Beta carotene content $(\mu \mathrm{g} / 100 \mathrm{~g})$ of mango fruits at different stages after fruit setting.

\begin{tabular}{|c|c|c|c|c|}
\hline \multirow{2}{*}{ S.No. } & \multirow{2}{*}{ Varieties } & \multicolumn{3}{|c|}{ Beta carotene content (mg/100g) } \\
\cline { 3 - 5 } & & $\mathbf{3 0}$ days & $\mathbf{6 0}$ day & $\mathbf{9 0}$ days \\
\hline 1 & Amrapali & 124.94 & 1442.71 & 3543.80 \\
\hline 2 & Langara & 121.30 & 1287.52 & 3254.75 \\
\hline 3 & Dashehari & 119.04 & 1263.53 & 3107.99 \\
\hline 4 & Safeda & 115.32 & 1153.00 & 3065.62 \\
\hline 5 & Rataul & 117.00 & 1069.86 & 2862.35 \\
\hline 6 & Gulabkhash & 109.25 & 1029.97 & 2801.67 \\
\hline 7 & Totapari & 104.03 & 1011.22 & 2719.17 \\
\hline 8 & Ramkela & 99.73 & 973.99 & 2650.52 \\
\hline 9 & Sukul & 95.59 & 900.70 & 2668.32 \\
\hline 10 & Gilash & 95.11 & 851.95 & 2572.63 \\
\hline & SEm+ & 1.55 & 20.55 & 38.17 \\
\hline & CD at $5 \%$ & 4.60 & 61.04 & 113.39 \\
\hline
\end{tabular}


Table 9: Crude fibre content (\%) of mango fruits at different stages after fruit setting.

\begin{tabular}{|c|c|c|c|c|}
\hline \multirow{2}{*}{ S.No. } & \multirow{2}{*}{ Varieties } & \multicolumn{3}{|c|}{ Crude fibre content (\%) } \\
\hline & & 30 days & 60 day & 90 days \\
\hline 1 & Amrapali & 1.12 & 0.88 & 0.62 \\
\hline 2 & Langara & 1.16 & 0.90 & 0.65 \\
\hline 3 & Dashehari & 1.14 & 0.93 & 0.68 \\
\hline 4 & Safeda & 1.17 & 0.95 & 0.69 \\
\hline 5 & Rataul & 1.19 & 1.01 & 0.74 \\
\hline 6 & Gulabkhash & 1.21 & 1.04 & 0.77 \\
\hline 7 & Totapari & 1.23 & 1.00 & 0.76 \\
\hline 8 & Ramkela & 1.24 & 1.08 & 0.61 \\
\hline 9 & Sukul & 1.26 & 1.10 & 0.82 \\
\hline 10 & Gilash & 1.28 & 1.11 & 0.85 \\
\hline & SEm \pm & 0.01 & 0.02 & 0.01 \\
\hline & CD at $5 \%$ & 0.03 & 0.05 & 0.04 \\
\hline
\end{tabular}

\section{Conclusion}

On the basis of overall results it can be concluded that green, dark green, yellow green, light green, light yellow and redish yellow colour were observed in different varieties from fruit setting to harvest stage. Maximum pulp weight was found in Dashehari at 30 days followed by langara at 60 days and 90 days. Highest total sugar and non-reducing sugar content were noticed in Amrapali at 30 and 60 days while Langara at 90 days after fruit setting. Maximum beta carotene content was observed in Amrapali followed by Langara at various intervals while ascorbic acid content was noticed maximum in Sukul at 30 days, Gilash at 60 days and Langara at 90 days after fruit setting.

\section{References}

1. AOAC. Association of official and analytical chemists, official method of analysis, $11^{\text {th }}$ Edn, Washington, DC, 1970, 438.

2. Azad MI, Mortuza Mg, Al-Amin MM, Naher NA, Alam SMK. Qualitative analysis of mango fruit at different maturity stages. The Agri. Jour. Of Krishi Foun. 2009; 7(1\&2):1-5.

3. Chesworth JM, Stuchbury T, Scaife JR. In: An introduction to Agricultural Biochemistry, 1998, 359362.

4. Dubois M, Cilles RA, Hamilton JK, Rubers PA, Smith F. Use of phenol reagent for the determination of total sugars. Anal. Chem, 1956, 28-350.

5. Hart FL, Fisher HJ. Modern food analysis. Springer Verlag, New York, 1971.

6. Hossain A, Rana A, Kimura Y, Roslan HA. Changes in biochemical characters and activities of ripening associated enzymes in mango fruit during the storage at different temperatures. Bio. Med. Res. Intr. Harwani Publ. Corp, 2014, 11.

7. Ishu MO. Comparative proximate composition of the fruits juice of three varieties of mango. M.Sc. Dissertation, Benue State University, Makurdi, Nigeria, 2013.

8. Mbogo G, Mubofu P, Egid B, Othman CC. Postharvest changes in physiochemical properties and level of some inorganic elements in vine ripened orange (Citrus Sinensis) fruits cv (Navel and valencia) of Tanzania Africa Jour. Biotech. 2010; 9(12):1809-1815.

9. Miller US, Kumar S. Use of dinitrosalicylic acid reagent for determination of reducing sugars. Annals Chem. 2005; 31:426-428.

10. Okoth EMl, Sila DN, Onyango CA, Owino WO, Musyimi SM, Mathooko FM. Evaluation of chemical and nutritional quality attributes of selected mango varieties at three stages of ripeness, growth in lower eastern province. Jour. Animal \& Plant Sci. 2013; 17(3):26192630.

11. Othman, Mbogo. Physicochemical characteristics of storage ripened mango, Tanz. J Sci, 2009, 35.

12. Rangana SS. Hand book of analysis and analysis and quality control of fruits and vegetable product, $2^{\text {nd }}$ ed. Tata Mc Graw, Hill Publishing com; Ltd; N. Delhi, 1986.

13. Siddig RA, Osman MS, Goj A, Elsiddig EAM. Physico chemical characteristics of three mango cultivars in Central Sudan, Intr. Jour. Sci. Res. Publ. 2016; 6:447.

14. Singh S, Rakha R, Kumar R, Singh M. Studies on quality parameters in mango pulp stored in containers at different temperatures, Intr. Res. Jour. Adv, Engi, Sci. 2017; 2(1):208-210.

15. Ubwa ST, Ishu MO, Offem JO, Tyohemba RL. Igbum proximate composition and some physical attributes of three mango fruit varieties. ISSN: 2223-7054 (Print). 2014; 2225-3610:4(2)(2):21-29. 